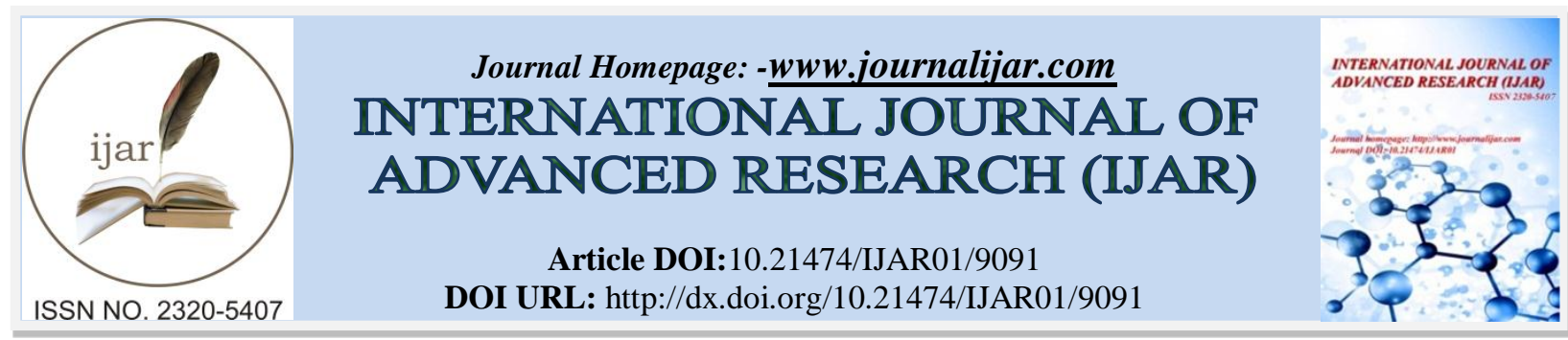

RESEARCH ARTICLE

\title{
AWARENESS ABOUT THE RIGHT TO EDUCATION (RTE) ACT AMONG ENGLISH MEDIUM SCHOOL TEACHERS OF STANDARD IST TO VIIITH OF THE ICSE BOARD - AN ACTION RESEARCH PROJECT.
}

\author{
Ms. Sandychris Inchiparamban ${ }^{1}$ and Dr. Elvina Pereira ${ }^{2}$. \\ 1. B.Ed. Student (2012-13), St. Xavier's Institute of Education, Mumbai. \\ 2. Assistant Professor, St. Xavier's Institute of Education, Mumbai.
}

\section{Manuscript Info}

Manuscript History

Received: 16 March 2019

Final Accepted: 18 April 2019

Published: May 2019

Key words:-

Right to Education Act, RTE, teachers.

\begin{abstract}
The Government of India, to ensure education for all, passed the Right to Education (RTE) Act in 2009. This act provides for the free and compulsory education of all children between the ages of six and fourteen. An important factor in making the RTE successful is teachers, and it is, therefore, important that teachers are aware about the basics of this act. This action research project was carried out to determine the awareness of the RTE Act among teachers teaching in English medium schools of the ICSE board.
\end{abstract}

Copy Right, IJAR, 2019,. All rights reserved.

\section{Introduction:-}

According to the Ministry of Human Resource Development of India, the Right to Education Act secures the right of children to free and compulsory education till the completion of elementary education in a neighbourhood school. The Act lays down the norms and standards relating to pupil teacher ratios, buildings and infrastructure, school working days and teacher working hours. Through the implementation of the RTE Act, the Government of India hopes to achieve $100 \%$ literacy rate in India.

\section{Need for the Study}

Teachers are a very important factor in making the RTE Act a success. Teachers would play an important role in implementing the RTE Act effectively. A lack of awareness on the part of the teachers about the RTE Act and its provisions could create major problems in education. This study will help in knowing the awareness about the Right to Education (RTE) Act among teachers which, in turn, will help in developing a positive attitude among teachers toward the Act and help them discharge their duties more effectively and efficiently.

\section{Aim}

The present study was undertaken to determine the awareness about the Right to Education (RTE) Act among the English medium school teachers of standard Ist to VIIIth of the ICSE Board.

\section{Methodology:-}

The descriptive methodology was used for this study. 


\section{Sample and Sampling Technique Sample}

The sample was 30 teachers teaching students in standards Ist to VIIIth in two schools affiliated to the ICSE board and located in South Mumbai. The purposive sampling technique was used; data was collected from the schools that gave permission for the same.

\section{Tool}

The questionnaire, constructed solely for the purpose of understanding the awareness about the RTE Act, 2009 among teachers, is based on various articles written on the Act and the Amendment passed by the Government of India regarding the same. Six major categories of the RTE Act, 2009, that is, (1) the preliminaries of the Act, (2) the child, (3) the teacher, (4) the infrastructure facilities, (5) capitation fees and screening procedures, and (6) the school management committee, were considered while constructing the tool.

\section{Data Analysis}

Percentage analysis was used to analyze the responses received from the teachers, and compare the percentage of correct responses to that of the incorrect responses for each question in each of the six categories.

\section{Findings}

The findings and their subsequent interpretations are given for each category, that is, (1) the preliminaries of the Act, (2) the child, (3) the teacher, (4) the infrastructure facilities, (5) capitation fees and screening procedures, and (6) the school management committee.

\section{The Preliminaries of the RTE Act:}

As regards the preliminaries, it was observed that most of the teachers are aware of the same. They are aware of most of the features of the preliminaries of the Act such as its abbreviation and its full form, the responsibilities of both houses of the Parliament with respect to the Act, and the criteria that the Act specifies with respect to the age group and the different types of children for whom the RTE Act is applicable.

\section{The Child:}

It was observed that the teachers have good awareness of the provisions of the RTE Act with respect to the child. The teachers are abreast with the features of the RTE Act that deal with the child such as not punishing or holding back the child, non-requirement of any kind of proof of birth for admission purposes, and the child's mother tongue as the medium of instruction.

\section{The Teacher:}

With regards to the provisions for the teacher in the Right to Education (RTE) Act, 2009, it was found that the teachers were aware of some duties while unaware of the others. For instance, the teachers were well acquainted with their duties both in and outside the school. However, most were not very sure about the number of working hours they are supposed to put in per week as well as per year.

\section{The Infrastructure Facilities:}

It was found that the teachers were well aware of the provisions for infrastructure facilities mentioned in the RTE Act, 2009 such as separate toilets for girls and boys in a co-educational school, safe and adequate drinking water facilities, and a clean and hygienic kitchen for the purpose of preparing mid-day meals.

\section{Capitation Fees and Screening Procedures:}

Findings indicate that most teachers are aware about the provision in the Right to Education (RTE) Act that restricts or prohibits the schools from charging any kind or amount of capitation fee and refrains schools from conducting any sought of screening process for the student or the parents.

\section{The School Management Committee:}

It was found that most teachers were not aware about the School Management Committee, a body expected to be set up in schools to ensure the smooth and efficient implementation of the Right to Education (RTE) Act, 2009. 


\section{Conclusion:-}

The study indicates that teachers are mostly aware about the provisions of the RTE Act, 2009. However, since teachers are an integral part of the education process, it would only be prudent that they keep themselves updated about the amendments to the Act and any other policies formulated for the education sector.

\section{References:-}

1. Inchiparamban, S. and Pereira, E. (2013). A study of the awareness about the Right to Education (RTE) Act among the English medium school teachers of standard Ist to VIIIth of the ICSE Board. (Unpublished B.Ed. action research project). St. Xavier's Institute of Education, Mumbai, India.

2. The Right of Children to Free and Compulsory Education Act, 2009. (2009). The Gazette of India. Retrieved May 20, 2019 from http://eoc.du.ac.in/RTE\%20-\%20notified.pdf

3. Right to Education. (2019). Retrieved May 20, 2019 from https://mhrd.gov.in/rte. 